\title{
頭部外傷における神経集中治療の理論と実践
}

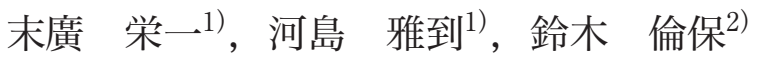 \\ 1）国際医療福祉大学医学部脳神経外科学，2）山口大学医学部先進温度神経生物学
}

\section{Theory and Practice of Neurocritical Care for Traumatic Brain Injury}

\author{
Eiichi Suehiro, M.D., Ph.D. ${ }^{1)}$, Masatou Kawashima, M.D., Ph.D. ${ }^{1)}$, and Michiyasu Suzuki, M.D., Ph.D. ${ }^{2)}$ \\ 1) Department of Neurosurgery, International University of Health and Welfare, School of Medicine, 2) Department of
} Advanced ThermoNeuroBiology, Yamaguchi University School of Medicine

In each patient with traumatic brain injury, the pathology is different, and cerebral blood flow and metabolism changes over time. In such a situation, attention is being paid to neurocritical care, which provides appropriate treatment under monitoring. The emphasis of neurocritical care is (1) cerebral perfusion pressure/intracranial pressure management; (2) infusion/electrolyte management; (3) respiratory management; (4) sedation/analgesic management; (5) body temperature management; and (6) diagnostic treatment for convulsions. In recent years, the development of neurocritical care has been remarkable, and many results have been reported. Neurocritical care algorithms using intracranial pressure monitoring or brain tissue oxygen partial pressure monitoring as indicators have been investigated and improved outcomes so that they can be easily practiced in daily medical care. In Japan as well, the spread of neurocritical care that makes full use of monitoring is expected to improve the outcome of severe traumatic brain injury.

(Received March 25, 2021 ; accepted April 1, 2021)

Key words : traumatic brain injury, monitoring, neurocritical care, intracranial pressure, brain tissue oxygen partial pressure

Jpn J Neurosurg（Tokyo） $30: 720-725,2021$

\section{はじめに}

これまで頭部外傷に関する臨床研究においては，臨床 分類として入院時の Glasgow Coma Scale (GCS) score に よる重症度分類のみを用いたために適切な結果を導き出 すことができなかった ${ }^{11)}$ 。 なぜならば，この重症度分類 では頭部外傷の病態に関する情報は含まれていないから である。頭部外傷を病態解剖学的に分類すると, 硬膜外 血腫や硬膜下血腫, 脳挫傷, 外傷性くも膜下出血, 外傷 性脳室内出血, びまん性軸索損傷, びまん性脳腫脹と多
岐に分けられる ${ }^{11)}$. 頭部外傷の治療においては，これら の分類に関連して病態生理学的メカニズムを理解し, 特 定のアプローチを見出す必要がある ${ }^{11)}$ 。さらには，頭部 外傷の病態は経時的変化に富んでいる。特に受傷後 24 時間以内では，頭部外傷による脳血流の低下や脳組織代 謝の立進が認められ，損傷脳は相対的虚血状態にあ $3^{1) 8)}$ ，そのため，二次性脳損傷が誘導され病態は常に変 化する。このような背景を根拠に，頭部外傷の治療にお いては evidence-based medicine ではなく, individualbased medicine が推奨される。つまり，頭部外傷の治療

連絡先：末廣栄一， 干 286-8520 成田市畑ヶ田 852 国際医療福祉大学成田病院脳神経外科

Address reprint requests to: Eiichi Suehiro, M.D., Ph.D., Department of Neurosurgery, International University of Health and Welfare, School of Medicine, 852 Hatakeda, Narita-shi, Chiba 286-8520, Japan 


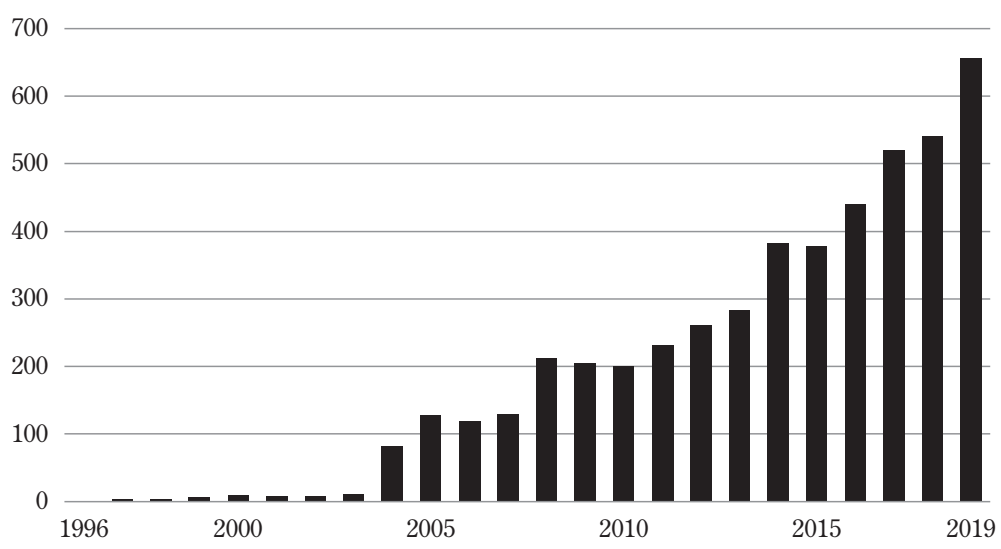

Fig. 1 Number of papers on neurocritical care

The number of papers searched for "neurocritical care" using Pub Med is shown. The number of papers has increased rapidly since Neurocritical Care Society was established in 2003.

においては，神経モニタリングを駆使して病態を経時的 に把握し，脳と全身をバランスよく管理する神経集中治 療が適している。

神経集中治療の源流は, 1923 年の Johns Hopkins 大学 における Neurosurgical ICU（NSICU）であるとされてい る ${ }^{13)}$. 1958 年には Mayo Clinicに Neuro ICU が開設され た ${ }^{13)}$. 1960〜1970 年代にかけて NSICU が米国にて多く 誕生している ${ }^{13)}$. 1990年代に neurology の subspecialty と して critical care neurology が確立し，2003 年に米国の Neurocritical Care Society（NCS）が設立された。これを 機に, 神経集中治療に関する論文が急増し (Fig. 1), 学 問としても発展してきた。しかし，日本ではまだなじみ の薄い領域である。日本集中治療医学会では, 神経集中 治療ハンズオンセミナーを開催し, 普及に努めている. あるいは，NCS が主催する Emergency Neurological Life Support (ENLS)の日本語版も日本にて開催されている。 本稿では，頭部外傷における神経集中治療の理論につい て解説し, 日本での普及により重症頭部外傷の転帰改善 を期待したい.

\section{神経集中治療とは}

神経集中治療とは，脳神経外科や脳神経内科，集中治 療など各分野の専門医や看護スタッフ, 薬剤師, 理学療 法士，臨床工学技士などの多職種からなるチーム医療で ある。重篤な一次性脳損傷の治療や二次性脳損傷の予 防，患者回復の促進，神経学的機能予後の改善などを共 通の目標として治療にあたる7)．神経集中治療の最も重 要な業務は，(1)脳灌流圧・頭蓋内圧の管理，(2)輸液電解
質管理，(3)呼吸管理，(4)鎮静疼痛管理，(5)体温管理，6) 痤攣の診断治療，の6つであるといわれている77.これ らの項目の目標を達成すべく脳と全身をバランスよく管 理するのが神経集中治療である。

次に神経集中治療が予後改善に，本当に効果的である のかどうか検証する，Kramer ${ }^{6)}$ は，重症中枢神経疾患 に対してNeuro ICUで治療を行った患者群と General ICU で治療を行った患者群の転帰を, メ夕解析にて比較 検討した。結果は，Neuro ICU で治療を行った患者群は 有意に予後が良好であった (OR 1.29, 95\%CI 1.11〜 1.51， $\mathrm{p}=0.001)^{6)}$. しかし，おのおのの研究にて神経集中治療 の効果の程度は大きく異なり, さらに詳細な検証が必要 と考えられる ${ }^{6)}$.また, Sekhon $ら^{12)}$ は，単施設での検討 であるが，神経集中治療を導入する前は重症頭部外傷の 転帰良好率は $37 \%$ であったが，神経集中治療を導入後は 60\%まで改善したと報告している。ささらに詳細に検証す ると, 神経集中治療の導入により体温や電解質が有意に 正常範囲内で管理されていた ${ }^{12)}$ 。また，昇圧剤の使用頻 度が増え，平均血圧は有意に上昇していた ${ }^{12)}$ 。これは, 脳灌流圧がより正確に管理された結果であろうと推察さ れる. 結果として, 神経集中治療の導入後は, 平均の頭 蓋内压は低下しており転帰良好率の改善へと導かれたと 思われる ${ }^{12)}$. 本研究より, 先述した神経集中治療の最も 重要な 6 つの管理により, 二次性脳損傷を防ぎ，結果と して頭蓋内圧立進を防ぎ得ることがわかる，通常の診療 では，頭蓋内圧充進の徵候を検知し頭蓋内圧を下げる治 療を行っている. しかし, 頭蓋内圧の上昇は二次性脳損 傷の結果として生じているので, 治療開始のタイミング としては “too late!” なのである。重症頭部外傷の管理に 


\title{
Vasodilatation cascade \\ $\mathrm{MABP} \Omega \Rightarrow \mathrm{CPP} \Omega \Rightarrow$ Vasodilatation $\Rightarrow \mathrm{CBV} \hat{\imath} \Rightarrow \mathrm{ICP} \hat{\imath}$ \\ Dehydration \\ Pharmacologic \\ $\mathrm{CMRO}_{2}$ 亿 \\ Viscosity

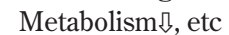 \\ Oxygen delivery Љ \\ $\mathrm{PaCO}_{2}$ 亿 \\ Pharmacologic, etc
}

\section{Vasoconstriction cascade}

\section{$\mathrm{MABP} \uparrow \Rightarrow \mathrm{CPP} \uparrow \Rightarrow$ Vasoconstriction $\Rightarrow \mathrm{CBV} \Omega \Rightarrow \mathrm{ICP} \Omega$}

\author{
Vascular volume $\hat{\imath}$ \\ Pharmacologic \\ $\mathrm{CMRO}_{2}$ ת \\ Metabolism 仓, etc \\ Viscosity § \\ Oxygen delivery $\hat{\imath}$ \\ $\mathrm{PaCO}_{2}$ 凡 \\ Pharmacologic, etc
}

Fig. 2 Relationship between blood pressure fluctuations and intracranial pressure due to cerebrovascular autoregulation

Owing to the ability of cerebrovascular autoregulation, intracranial pressure increases as blood pressure decreases. Conversely, an increase in blood pressure reduces intracranial pressure.

MABP : mean arterial blood pressure, CPP : cerebral perfusion pressure, $\mathrm{CBV}$ : cerebral blood volume, ICP : intracranial pressure, $\mathrm{CMRO}_{2}:$ cerebral metabolic rate of oxygen

おいては，“too late”になる前に神経集中治療の最も重 要な 6 つの管理を徹底し, 頭部外傷の重篤化を防ぐこと が重要である.

\section{適切な脳灌流圧管理とは}

神経集中治療の重要な管理項目に脳灌流圧の管理が含 まれている，頭部外傷治療・管理のガイドライン9゙によ ると，脳灌流圧は $50 \sim 70 \mathrm{mmHg}$ を目安に管理するよう に勧められているが，適正值は個々の症例により異なる と但し書きがある，正確には，その適正值がわからなけ れば脳灌流圧を管理することはできないことになる。し かし, 脳灌流圧の適正值について述べている教科書は少 ないので，本稿で説明したい.

実は，個々の症例の脳血管自動調節能の障害程度によ り適切な脳灌流圧は変化する。脳は脳血管自動調節能と いう，血圧の変動に対して脳血流を一定に保とうとする 機能を備えている. 脳血管自動調節能が正常であれば, 血圧が低下すると脳血流を保つために脳血管は拡張し脳 血液量は上昇し頭蓋内圧も上昇する（Fig. 2)。逆に，血 圧が上昇すると，逆の作用により頭蓋内压は低下する

(Fig. 2)。この原理を用いて, ベッドサイドで脳血管自動 調節能をモニタリングできる指標として pressure reactivity index (PRx) が知られている ${ }^{5)}$. PRxは, 頭蓋内圧
と血圧変動の相関係数を算出したものである，脳血管自 動調節能が正常であれば PRxは負の值を示す．脳血管自 動調節能が障害されていれば PRx は正の值を示すこと になる。

まず，脳血管自動調節能が正常な場合を考えてみる. この場合，血圧の変動に対して PRxは，常に負の值を示 す（Fig. 3A）。また，通常血圧の範囲内であれば脳血流 は一定であり，頭蓋内圧値と血圧值は反比例の関係とな る（Fig. 3A）。それに対して，頭部外傷により脳血管自 動調節能が障害されている場合，正常な脳血流を維持で きる血圧の範囲は限局的である (Fig. 3B)。その限局範 囲内では PRx は負の值を示し, 頭蓋内圧值と血圧值は反 比例の関係となるが，それ以外の範囲では PRx は正の值 を示し，頭蓋内圧值と血圧值は比例の関係となる（Fig. 3B)。これらの原理を踏まえて，頭部外傷症例における $\mathrm{PRx}$ と脳灌流圧の関係を図示すると Fig. 3C のように, 正常な脳血流を維持できている脳灌流圧では PRx は負 の值を示し，それ以外の脳灌流圧では PRx は正の值を示 すのである。つまり，PRxが最も低值を示したときの脳 灌流圧が個々の症例における適正な脳灌流圧となる

(Fig. 3C).

Donnelly ら $^{3)}$ は, 1992〜2017 年までの 25 年間における 神経集中治療の変遷について報告している。1990 年代 は，過換気療法を頻用し，脳灌流圧を $70 \mathrm{mmHg}$ 以上に 
A Normal condition

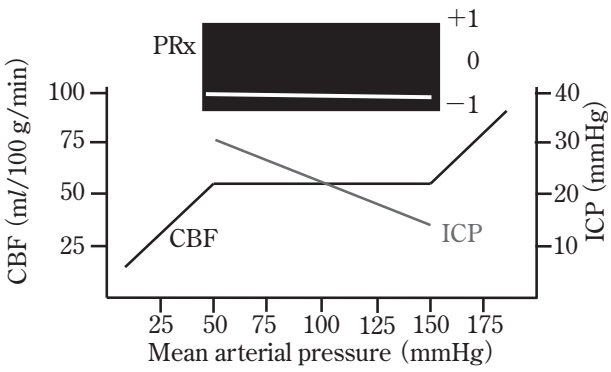

C Optimal CPP

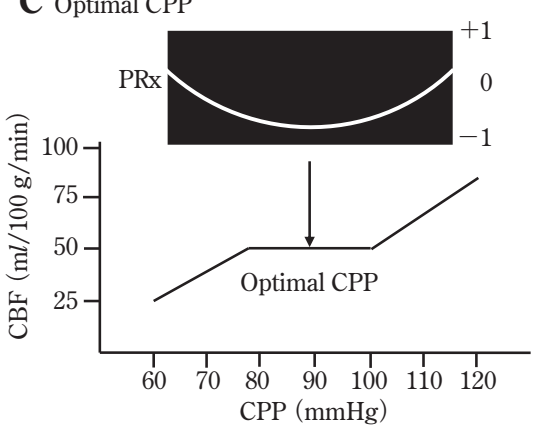

B Post brain injury

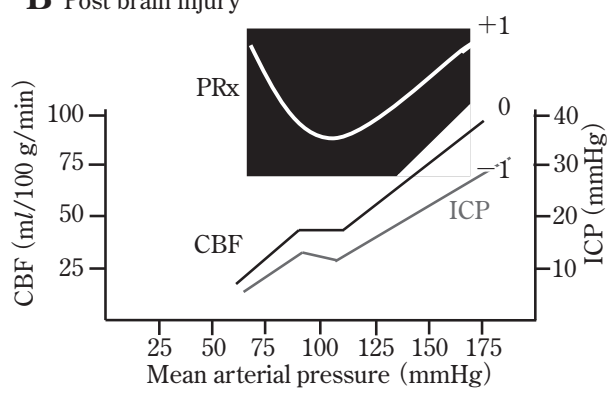

Fig. 3 Relationship between blood pressure (CPP) and cerebral blood flow/PRx Relationship between each parameter in (A) normal condition or (B) post-brain injury. (C) CPP with the lowest PRx value was the optimal CPP.

$\mathrm{PRx}$ : pressure reactivity index, $\mathrm{CBF}$ : cerebral blood flow, ICP : intracranial pressure, $\mathrm{CPP}$ : cerebral perfusion pressure

なるように管理していた ${ }^{3)}$. しかし，2000 年代に入ると 過換気療法の施行頻度は減少し, マルチモーダルセン サーを使用して適正な脳灌流圧による管理へと移行して いる ${ }^{3)}$ ，適正な脳灌流圧による管理へと変遷した結果， 平均の脳灌流圧は $70 \mathrm{mmHg}$ から $75 \sim 80 \mathrm{mmHg}$ と上昇 している，また，興味深いことに頭部外傷の重症度は変 わっていないが，頭蓋内圧の平均值は有意に低下し，頭 蓋内圧充進の頻度も減少している3 。前項でも述べたよ うに，適正な脳灌流圧による管理を行うことにより二次 性脳損傷を予防し, 頭蓋内圧元進による予後の悪化抑制 効果が実証されている.

\section{頭蓋内圧モニタリングを用いた 頭部外傷管理のアルゴリズム}

頭部外傷の病態の多様性がゆえに，頭部外傷診療にお いては evidence-based medicine から individual-based medicine 几と移行しつつある。そこで，おのおのの病態 にリアルタイムに対応しながら治療を行うべく, 頭蓋内 圧を指標とした治療アルゴリズムが作成された 陸から 10 名の神経集中治療医，23 名の脳神経外科医，5 名の脳神経内科医, 2 名の外傷外科医, 2 名の救急医が参
加してコンセンサスが得られたアルゴリズムである.

1 Treatment not recommended for use in the management of severe traumatic brain injury (TBI)

以下の処置は重症頭部外傷の管理において勧められな いと提示されている. (1)マンニトールの（急速でない） 持続静注，(2)高浸透圧利尿剂の定期投与，(3)腰椎からの 髄液ドレナージ，(4)フロセミドの使用，(5)ステロイドの 使用， (6 $35^{\circ} \mathrm{C}$ 以下の低体温療法の安易な導入，7 burst suppression 目的でのプロポフォールの大量投与, 8動脈 血中二酸化炭素分圧 $30 \mathrm{mmHg}$ 以下の過換気療法の安易 な導入，9脳灌流圧 $90 \mathrm{mmHg}$ 以上への安易な昇圧，の 9 つである4).

\section{Tier Zero (basic severe TBI care)}

次に，重症頭部外傷の管理において，必ず行うべき処 置を提示する。(1)ICU に入室する，(2)経口抻管とし人工 呼吸管理を行う，330〜45 度の高さで頭部挙上を行う， (4)適量の鎮静，鎮痛を行う，(5) $38^{\circ} \mathrm{C}$ 以上の発熱を防ぐべ く体温管理を行う，61 週間の抗痤攣薬の投与を考慮す る，(7)脳灌流圧を $60 \mathrm{mmHg}$ 以上に維持する，8へモグ 
ロビンは $7 \mathrm{~g} / \mathrm{d} l$ 以上に管理する，9低ナトリウム血症は 避ける，10静脈還流を確保できる頭位を考慮する，の 10 項目である ${ }^{4)}$.

\section{Tier 1}

Tier Zero の処置後，頭蓋内圧九進を認める場合は，以 下の処置を行う。(1)脳灌流圧を 60 ～70 mmHg の範囲で 維持する，(2)頭蓋内圧を下げるべく鎮静，鎮痛を強化す る, (3)動脈血中二酸化炭素分圧を正常下限である 35〜38 $\mathrm{mmHg}$ の範囲に維持する, (4)マンニトールや高張食塩水 の間欠的急速投与, (5)脳室ドレナージからの髄液排出, (6)脳波モニタリングの考慮，の 6 項目である ${ }^{4)}$.

\section{Tier 2}

Tier 1 の処置後, 頭蓋内圧六進を認める場合は, 以下 の処置を行う ${ }^{4)}$. (1) 動脈血中二酸化炭素分圧 $32 \sim 35$ $\mathrm{mmHg}$ の軽度過換気療法, (2)筋弛緩薬の増量, (3)MAP Challenge：昇圧剂を用いて血圧を $10 \mathrm{mmHg}$, 約 20 分間 昇圧する。この昇圧に反応して頭蓋内圧が低下した場 合, 脳血管自動調節能は障害されていないと判断される ため，昇圧によって脳灌流圧を維持する.

\section{Tier 3}

Tier 2 の処置後, 頭蓋内圧兇進を認める場合は, 以下 の処置を行う。(1)バルビッレート療法を導入する, (2)減 圧開頭術を行う，(3)軽度低体温療法 $\left(35 \sim 36^{\circ} \mathrm{C}\right)$ を導入 する，の 3 項目である ${ }^{4)}$.

\section{重症頭部外傷管理における マルチモダルセンサーの重要性}

頭蓋内圧九進には “原因” と “結果”, 2 つの側面があ り, 常に連鎖している。一次性/二次性脳損傷による結 果, 頭蓋内圧立進が生じる。 その頭蓋内圧元進が原因と なって二次性脳損傷を介し, さらなる頭蓋内圧充進が生 じる．前項で述べた頭蓋内圧管理は，原因としての頭蓋 内圧六進に対応して，さらなる頭蓋内圧充進を防ぐため の管理である。それに対して，マルチモダルセンサーを 用いた神経集中治療では適切な全身管理により, 一次 性/二次性脳損傷による頭蓋内圧六進を未然に防ぐ。そ のため，頭蓋内圧立進の連鎖も生じずに転帰も良好とな る. マルチモダルセンサーを用いた管理の 1 つとして脳 組織酸素分圧と頭蓋内圧を指標とした管理が，近年では


サー単独と頭蓋内圧センサーに加えて脳組織酸素分圧セ
ンサーを指標としたアルゴリズムを使用した患者群を比 較検討した。結果は，2つの指標を用いた患者群のほう が，脳組織の虚血時間や頭蓋内圧立進時間が短く，受傷 後 6 力月の転帰も良好であった ${ }^{10)}$ 。つまり, 一次性/二次 性脳損傷による頭蓋内圧方進を未然に防ぎ，負の連鎖に 陥ることなく頭蓋内圧管理が可能であった。日本では， 現在，頭蓋内圧センサーのみが使用可能で脳組織酸素分 圧の測定はできないため，前項では頭蓋内圧モニタリン グを用いたアルゴリズムを紹介した．欧米では，脳組織 酸素分圧も含めたマルチモダルセンサーによる管理が一 般的となっており，その管理アルゴリズムも公表されて いる2．今後は，日本でもマルチモダルセンサーを用い た神経集中治療が可能となる環境が待たれる。

\section{おわりに}

頭部外傷に対する神経集中治療の概略について解説し た。神経集中治療とは多職種によるチーム医療であり， 脳指向型全身管理を行い頭蓋内の病態生理を安定化させ る行為である，頭部外傷の治療では，頭蓋内圧の管理の みに注意が集まりがちであるが，脳循環代謝を安定さ せ，脳の酸素化が十分であれば頭蓋内圧はあまり立進し ない. 日本においても, 神経集中治療が浸透し, 重症頭 部外傷の治療成績が改善することが望まれる。

\section{COIについて}

著者全員は日本脳神経外科学会への COI 自己申告の登録を 完了しています。

本論文に関して開示すべきCOI はありません.

\section{文 献}

1) Bouma GJ, Muizelaar JP, Choi SC, Newlon PG, Young HF : Cerebral circulation and metabolism after severe traumatic brain injury : the elusive role of ischemia. J Neurosurg 75: 685-693, 1991.

2) Chesnut R, Aguilera S, Buki A, Bulger E, Citerio G, Cooper DJ, Arrastia RD, Diringer M, Figaji A, Gao G, Geocadin R, Ghajar J, Harris O, Hoffer A, Hutchinson P, Joseph M, Kitagawa R, Manley G, Mayer S, Menon D, Meyfroidt G, Michael DB, Oddo M, Okonkwo D, Patel M, Robertson C, Rosenfeld JV, Rubiano AM, Sahuquillo J, Servadei F, Shutter L, Stein D, Stocchetti N, Taccone FS, Timmons S, Tsai E, Ullman JS, Vespa P, Videtta W, Wright DW, Zammit C, Hawryluk GWJ : A management algorithm for adult patients with both brain oxygen and intracranial pressure monitoring : the Seattle International Severe Traumatic Brain Injury Consensus Conference (SIBICC). Intensive Care Med 46 : 919-929, 2020.

3) Donnelly J, Czosnyka M, Adams H, Cardim D, Kolias AG, Zeiler FA, Lavinio A, Aries M, Robba C, Smielewski P, Hutchinson PJA, Menon DK, Pickard JD, Budohoski KP : 
Twenty-five years of intracranial pressure monitoring after severe traumatic brain injury: a retrospective, single-center analysis. Neurosurgery $\quad 85$ : E75-E82, 2019.

4) Hawryluk GWJ, Aguilera S, Buki A, Bulger E, Citerio G, Cooper DJ, Arrastia RD, Diringer M, Figaji A, Gao G, Geocadin R, Ghajar J, Harris O, Hoffer A, Hutchinson P, Joseph M, Kitagawa R, Manley G, Mayer S, Menon DK, Meyfroidt G, Michael DB, Oddo M, Okonkwo D, Patel M, Robertson C, Rosenfeld JV, Rubiano AM, Sahuquillo J, Servadei F, Shutter L, Stein D, Stocchetti N, Taccone FS, Timmons S, Tsai E, Ullman JS, Vespa P, Videtta W, Wright DW, Zammit C, Chesnut RM : A management algorithm for patients with intracranial pressure monitoring : the Seattle International Severe Traumatic Brain Injury Consensus Conference (SIBICC). Intensive Care Med $45:$ 1783-1794, 2019.

5) Koizumi H, Suehiro E, Fujiyama $Y$, Sugimoto K, Inoue $T$, Suzuki M: Update on intensive neuromonitoring for patients with traumatic brain injury: A review of the literature and the current situation. Neurol Med Chir (Tokyo) 54: 870-877, 2014.

6) Kramer AH, Zygun DA : Do neurocritical care units save lives? Measuring the impact of specialized ICUs. Neurocrit Care 14:329-333, 2011.

7）黒田泰弘：神経集中治療の今後の展望一日本における神 経集中治療のあるべき姿を考える一. Intensivist $\mathbf{5}$ : 469-481, 2013.
8) Marion DW, Darby J, Yonas H : Acute regional cerebral blood flow changes caused by severe head injuries. J Neurosurg 74: 407-414, 1991.

9）日本脳神経外科学会, 日本脳神経外傷学会監：頭部外傷 治療・管理のガイドライン作成委員会編：頭部外傷治 療・管理のガイドライン 第 4 版. 東京, 医学書院, 2019 .

10) Okonkwo DO, Shutter LA, Moore C, Temkin NR, Puccio AM, Madden CJ, Andaluz N, Chesnut RM, Bullock MR, Grant GA, McGregor J, Weaver M, Jallo J, LeRoux PD, Moberg D, Barber J, Lazaridis C, Diaz-Arrastia RR : Brain oxygen optimization in severe traumatic brain injury phase ${ }^{-}$ II : a phase II randomized trial. Crit Care Med $45: 1907-$ 1914, 2017.

11) Saatman KE, Duhaime AC, Bullock R, Maas AIR, Valadka A, Manley GT, Workshop Scientific Team and Advisory Panel Members : Classification of traumatic brain injury for targeted therapies. J Neurotrauma 25:719-738, 2008.

12) Sekhon MS, Gooderham P, Toyota B, Kherzi N, Hu V, Dhingra VK, Hameed MS, Chittock DR, Griesdale DE : Implementation of neurocritical care is associated with improved outcomes in traumatic brain injury. Can J Neurol Sci 44:350-357, 2017.

13) Wijdicks EF : The history of neurocritical care. Handb Clin Neurol 140:3-14, 2017.



